\title{
Provenance of the Early Cambrian Abbottabad Formation in the Hazara region, Pakistan
}

\section{Sciendo}

Inam ur Rahim*a,b, Shahid Ghazib, Shahid Alib , Qamar Uz Zaman Darc, Noman Zeb

aOil \& Gas Development Company Limited, Jinnah Avenue F-6/1, Isalamabad, Pakistan

bInstitute of Geology, University of the Punjab, Lahore-54590, Pakistan

'Department of Geology, Northwest University Xian-710069, China

*Corresponding author e-mail: inam1991@gmail.com

\section{DOI: 10.2478/pjg-2019-0009}

\section{Abstract:}

The early Cambrian Abbottabad Formation mainly comprises of dolomite, sandstone, shale and conglomerates at Khote-di-Qabar section, Hazara region, Pakistan. The formation makes lower contact with Hazara Formation and upper contact with Hazira Formation. The formation is comprehensively studied during the field and lab work to interpret its provenance. Five distinguishable sedimentary units including 1) Tanaki boulder bed; 2) Sanghargali siltstone/shale; 3) Mohammdagali Dolomite/quartzite; 4) Mirpur sandstone; 5) Sirban dolomite can be identified in the field that indicate variable depositional strata of the formation under various depositional setting. Additionally, petrographic analysis of Sanghargali siltstone/shale unit and Mirpur sandstone unit of the formation indicate the main lithologies of these units are litharenite and sublitharenite respectively. Moreover, the provenance of these sandstone units of the formation most probably belong to Aravali and Malani Ranges located in the South of the study area.

Keywords: Clast count method, Petrography, Provenance, Cambrian Abbottabad Formation, Hazara area, Pakistan.

\subsection{Introduction}

The early Cambrian Abbottabad Formation at Khote-di-Qabar section, Hazara region, Pakistan constitute of five distinguished units: 1) Tanaki boulder bed; 2) Sanghargali siltstone/shale; 3) Mohammdagali Dolomite/quartzite; 4) Mirpur sandstone; 5) Sirban dolomite. The basal contact of Abbottabad Formation is with Hazara Formation, which are predominantly slate in the study area. The upper contact of Abbottabad Formation is gradational with Hazira Formation marked on the basis of fauna, Hyolithies.

The Abbottabad Formation was named by Mark and Ali [1] for a set of predominantly dolomitic rocks with subordinate siliceous and argillaceous rocks from the Sirban Hill, Abbottabad. Ali [2] included similar lithologies exposed in the southern Tanawal region west of Abbottabad into the Abbottabad Formation. Calkins et al. [3], however, misinterpreted these lithologies to be of Triassic age and mapped them as Kingrialli Formation, a sandstone unit exposed in the Salt Range.

Recently, several researchers described the various aspect of the formation such as: Stratigraphic characterization of the Abbottabad Formation and correlation with NW Himalayas by Qasim et al. [4]; Geotechnical properties of Cambrian Dolomite, Abbottabad Formation by Khan et al. [5]. However, the comprehensive sedimentological and stratigraphic work of the Early Cambrian Abbottabad Formation is lacking. The present work describes the depositional environment and provenance of the formation through macro and microfabrics characteristics.

\subsection{Geological Setting}

The present location of Hazara area (Hazara Fold and Thrust Belt) is due to collision of Indo-Pakistan and Eurasian Plate at the end of cretaceous about 65 million years ago [6]. At start of Cretaceous the Indo-Pakistan subcontinent was present in Gondwana Region and located near Australia, Africa, Antarctica and southern America. The uplifting of the Himalayas resulted after World Plate kinematics resulted in reconstruction of pres ent day Himalayan landmass including Indo-Pakistan subcontinent which subsided below Eurasia. During the Journey of Indo-Pakistan Plate from South towards North caused close of Pangea and formed an island arc i.e. Kohistan Island Arc in Pakistan [7]. The Kohistan Island Arc kept its igneous activity for about 45 million years, after this magmatism back arc basin was finally closed and Kohistan Island Arc was accreted onto the Eurasia. In this way, Andean Plate margin was originated. Eventually, Powell [6] described five main boundaries from north to south (Fig. 1), which are controlled by major faults and depicting various tectonic forces and stratigraphic succession.

Hazrar area (Hazara Fold and Thrust Belt) is located between the main boundary thrust (MBT) in the south and the panjal thrust in the north (Fig. 1). Metamorphic, meta-sedimentary and sedimentary rocks aging from Pre-Cambrian to Miocene are exposed in the Hazara Basin. Structurally, Hazara Basin is located in compressional tectonic regime, with many thrusts, small and large scale folds and their overall north-east, south-west trend illustrating compressive stresses coming from northeast direction (Fig. 1). Pre-Cambrian Hazara Formation is oldest stratigraphic unit exposed in the area [8,9]. 


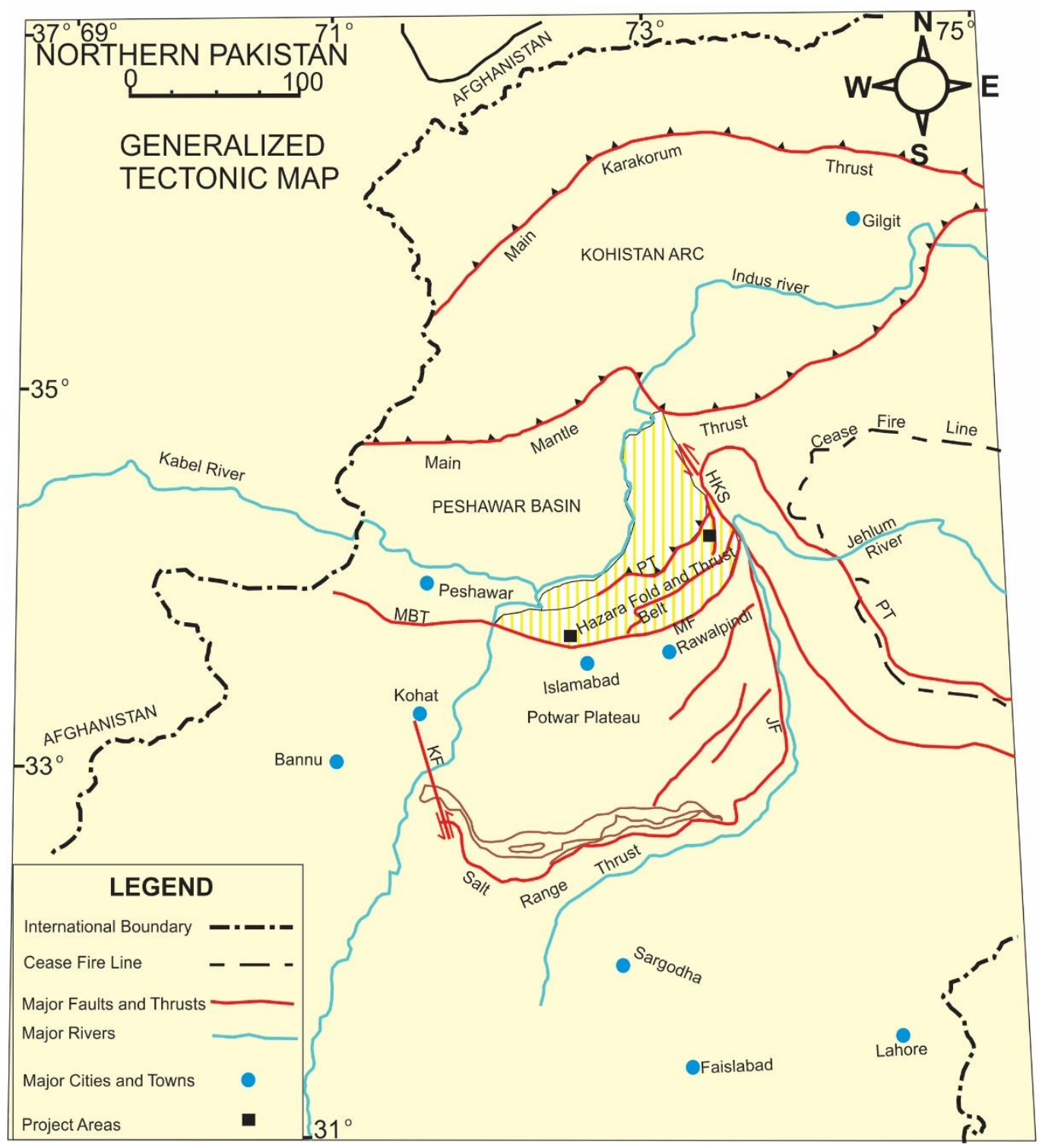

Figure 1: A generalized tectonic map showing major faults and tectonic regions along with the representation of project area (modified from [10])

The stratigraphic sequence exposed in south-eastern part of the Hazara composed of Precambrian to Miocene age rocks separated by different unconformities during Paleozoic time [3]. Latif [8] described seven lithostratiraphic units of southern Hazara, which further subdivided into twenty-one formations. Latterly, Shah [9] comprehensively described the Hazara strata. The comparison of Latif [8] and Shah [9] is given in Fig. 2. 


\begin{tabular}{|c|c|c|}
\hline $\begin{array}{c}\text { Stratigraphic } \\
\text { Nomenclature after Latif } \\
(\mathbf{1 9 7 0 )}\end{array}$ & $\begin{array}{c}\text { Stratigraphic } \\
\text { Nomenclature after Shah } \\
(1977)\end{array}$ & Age \\
\hline $\begin{array}{l}\text { Kamlial Formation } \\
\text { (Rawalpindi Group) }\end{array}$ & $\begin{array}{l}\text { Kamlial Formation } \\
\text { (Rawalpindi Group) }\end{array}$ & Mid- Late Miocene \\
\hline $\begin{array}{l}\text { Murree Formation } \\
\text { (Rawalpindi Group) }\end{array}$ & $\begin{array}{l}\text { Murree Formation } \\
\text { (Rawalpindi Group) }\end{array}$ & Early Miocene \\
\hline \multicolumn{3}{|c|}{ Unconformity } \\
\hline $\begin{array}{l}\text { Kuldana Formation } \\
\text { Lora Formation } \\
\text { Margala Hill Formation }\end{array}$ & $\begin{array}{l}\text { Kuldana Formation } \\
\text { Chorgali Formation } \\
\text { Margala Hill Limestone }\end{array}$ & Eocene \\
\hline $\begin{array}{l}\text { Kuza Gali shale } \\
\text { Mari Limestone } \\
\text { Not mentioned }\end{array}$ & $\begin{array}{l}\text { Patala Formation } \\
\text { Lockhart Formation } \\
\text { Hangu Formation }\end{array}$ & Paleocene \\
\hline \multicolumn{3}{|c|}{ Unconformity } \\
\hline $\begin{array}{l}\text { Chenali Limestone } \\
\text { Giumal Sandstone Group } \\
\text { Spitti Shale }\end{array}$ & $\begin{array}{l}\text { Kawagarh Formation } \\
\text { Lumshiwal Formation } \\
\text { Chichali Formation }\end{array}$ & Cretaceous \\
\hline \multicolumn{3}{|c|}{ Unconformity } \\
\hline $\begin{array}{l}\text { Sikhar Limestone } \\
\text { Maira Limestone group } \\
\text { Not reported }\end{array}$ & $\begin{array}{l}\text { Samana Suk Formation } \\
\text { Shinawari Formation } \\
\text { Datta Formation }\end{array}$ & Jurassic \\
\hline \multicolumn{3}{|c|}{ Unconformity } \\
\hline $\begin{array}{l}\text { Hazira Formation } \\
\text { Galdanian Formation } \\
\text { Sirban Formation } \\
\text { Kakul Formation }\end{array}$ & $\begin{array}{c}\text { Hazira Formation } \\
\text { Abbottabad Formation }\end{array}$ & Cambrian \\
\hline \multicolumn{3}{|c|}{ Unconformity } \\
\hline $\begin{array}{l}\text { Tanol Formation } \\
\text { Hazara Group }\end{array}$ & $\begin{array}{l}\text { Tanawal Formation } \\
\text { Hazara Formation }\end{array}$ & Pre-Cambrian \\
\hline
\end{tabular}

Figure 2: Different nomenclature of rock units exposed in southeast Hazara after Latif [8] and Shah [9]

\subsection{Material and Method}

The early Cambrian Abbottabad Formation, studied in Hazara Basin is exposed along Havelian-Abbottabad road near Abbottabad City. The coordinates of the Abbottabad Formation in Khote-di-Qabar section is bounded between longitudes $73^{\circ} 10^{\prime} 15.58^{\prime \prime}$ to $73^{\circ} 10^{\prime} 30.07^{\prime \prime}$ and latitudes $34^{\circ} 06^{\prime} 5.09^{\prime \prime}$ to $34^{\circ} 06^{\prime} 48.59^{\prime \prime}$ (Fig. 1). The sedimentary features of all five units of the formation observed during the field work and samples were only taken from two units i.e. Sanghargali Sand/shale and Mirpur unit of the formation to interpret the provenance of these particular units of the formation.

The provenance of Tanaki boulder bed is determined via clast count method. This method can provide the clues of tectonic activity, paleocurrent direction, depositional environment, mechanism of clast emplacement, and rheology of gravel [11]. According to this method, count the individual clast within a selected area of desired sample size [12]. The area must be at least 2.5 times the diameter of the largest clast. Clasts are classified into their respective lithologies accordingly; igneous, metamorphic and sedimentary. The data is plotted on the triangular diagrams which indicate the influence of lihologies. If the clasts of gravel fraction are truly spherical, it is sufficient to measure the diameter. But in majority of the cases it doesn't happen, in these situations it is better to measure long (a), intermediate (b) and short (c) axes of the clasts, measured along three mutually perpendicular lines. Where the conglomerates are well cemented, it is not easy to measure these. In such situations, it is convenient to determine the maximum particle size (MPS) by measuring the size (apparent long axis, as exposed) of ten largest clasts and taking their mean. It is also necessary to determine the bed thickness (BTh) of gravel/conglomerate bed. Plotting MPS vs. BTh data helps to discriminate a gravel/conglomerate bed of gravity flow origin from that of fluvial origin [11]. MPS vs. BTh data of the Tanaki Boulder Bed is given in Table 1. Clast count of the Tanaki Boulder bed in clast supported conglomeratic facies is carried out. 
Table 1: Maximum particle size (MPS) and bed thickness (BTh) data collected from the Abbottabad Formation (Tanaki Boulder Bed).

\begin{tabular}{|c|c|c|}
\hline S r.no & $\begin{array}{ccc}\text { M } & \text { P } & \text { S } \\
\left(\begin{array}{lll}\text { c } & \text { m }\end{array}\right)\end{array}$ & 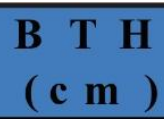 \\
\hline 1 & 5.5 & 20 \\
\hline 2 & 5 & 70 \\
\hline 3 & 3 & 50 \\
\hline 4 & 2 & 100 \\
\hline 5 & 5 & 120 \\
\hline 6 & 3 & 110 \\
\hline 7 & 1 & 60 \\
\hline 8 & 4.5 & 150 \\
\hline 9 & 5 & 160 \\
\hline 10 & 7 & 210 \\
\hline 11 & 8 & 170 \\
\hline 12 & 4 & 2000 \\
\hline 13 & 6 & 220 \\
\hline 14 & 9 & 230 \\
\hline 15 & 3 & 250 \\
\hline 16 & 10 & 270 \\
\hline 17 & 2 & 330 \\
\hline 18 & 2 & 310 \\
\hline 19 & 6.5 & 330 \\
\hline 20 & 7 & 400 \\
\hline 21 & 8 & 390 \\
\hline 22 & 6.5 & 420 \\
\hline 23 & 3 & 5000 \\
\hline 24 & 3.5 & $\begin{array}{lll}5 & 1 & 0\end{array}$ \\
\hline 25 & 2 & 550 \\
\hline 26 & 8 & 590 \\
\hline 27 & 2 & $\begin{array}{lll}6 & 10 & 0\end{array}$ \\
\hline 28 & 4 & $7 \begin{array}{lll}7 & 1 & 0\end{array}$ \\
\hline 29 & 7 & 650 \\
\hline 30 & 1.5 & 700 \\
\hline
\end{tabular}

In petrographic analysis, the provenance of Sanghargali Sand/shale and Mirpur unit of the Abbottabad Formation is measured via point count data method in which individual grains are counted and then plotted in ternary diagrams, the main framework grains are taken at each corner of triangle i.e. quartz at one end and feldspar and rock fragments at respective ends. Specialized ternary plots named after Dickinson`s and Weltje are used worldwide and basic compositional information is plotted on them. These plots give valuable information about tectonic history of the source rock [13]. Specialized Excel based electronic spreadsheet is adopted for sandstone classification and its origin (provenance) of these two units of Abbottabad Formation. Raw data from point count analysis can be directly given to the input worksheet. Point count data for Sanghargali sand/silt and Mirpur unit of the Abbottabad Formation are given in tables 2 and 5. Electronic spreadsheet (Table $3 \&$ 4; Sanghargali sand/silt unit and Table 6 \& 7; Mirpur unit) generates number of ternary plots which provide valuable information about its composition and provenance of the rock. The data used in electronic spreadsheet is given as: Monocrystalline Quartz = Qm; Polycrystalline Quartz = Qp; Total Quartz $(\mathrm{Qt})=\mathrm{Qm}+\mathrm{Qt}$; Potassium Feldspar = K; Plagioclase Feldspar = P; Volcanic Rock Fragment $=\mathrm{Lv} ;$ Igneous Rock Fragment $=$ Lp; Metamorphic Rock Fragment $=\mathrm{Lm}$. Six plots are drawn for each unit of the formation in which three plots of each unit consist of Dickinson's original model and Weltje's revision. Moreover, Folk and Dott's classification of each unit are also given. 
Table 2: Point count data of the Abbottabad Formation (Sanghargali Unit)

\begin{tabular}{|c|c|c|c|c|c|c|c|c|c|c|c|c|}
\hline \multirow{3}{*}{ Slide no } & \multicolumn{4}{|c|}{ Point Count Data } & \multirow{2}{*}{\multicolumn{3}{|c|}{ Rock Fragments }} & & & \multirow{3}{*}{$\begin{array}{l}\text { Total } \\
\text { Grains }\end{array}$} & \multirow{3}{*}{ Grain \% } & \multirow{3}{*}{ Matrix \% } \\
\hline & \multicolumn{2}{|c|}{ Quartz } & \multicolumn{2}{|c|}{ Feldspar } & & & & \multicolumn{2}{|c|}{ Mica } & & & \\
\hline & Monocrystalline & Polycrystalline & K-Feldspar & Plagioclase & Igneous & Metamorphic & Sedimentary & Muscovite & Biotite & & & \\
\hline $\mathrm{Sg} 1$ & 51 & 88 & 2 & 3 & 7 & 19 & 33 & 1 & 3 & 207 & $89.0 \%$ & $11.0 \%$ \\
\hline $\mathrm{Sg} 2$ & 33 & 101 & 1 & 7 & 5 & 11 & 21 & 5 & 2 & 186 & $87.0 \%$ & $17.0 \%$ \\
\hline $\mathrm{Sg} 3$ & 65 & 71 & 3 & 1 & 1 & 22 & 41 & 2 & 2 & 208 & $85.0 \%$ & $15.0 \%$ \\
\hline $\mathrm{Sg} 4$ & 77 & 53 & 1 & 3 & 1 & 10 & 49 & 3 & 1 & 198 & $84.0 \%$ & $16.0 \%$ \\
\hline
\end{tabular}

Table 3: Numerical values are calculated by using Microsoft Excel- based electronic spread sheet proposed by Zahid and Barbeau [13] which is used for calculating intra-ternary provenance fields.

\begin{tabular}{|c|c|c|c|c|c|c|c|}
\hline \multicolumn{8}{|c|}{ Dataset QmPK } \\
\hline \multicolumn{3}{|c|}{ Enter Raw Point Count Data Below } & \multicolumn{3}{|c|}{ Output Data } & \multirow{2}{*}{$\frac{2.86}{x}$} & \multirow{2}{*}{$\begin{array}{c}4.67 \\
y\end{array}$} \\
\hline Top & Left & Right & Top $\%$ & Left $\%$ & Right \% & & \\
\hline 51 & 3 & 2 & 91.07 & 5.36 & 3.57 & & \\
\hline 33 & 7 & 1 & 80.49 & 17.07 & 2.44 & 2.56 & 4.18 \\
\hline 65 & 1 & 3 & 94.20 & 1.45 & 4.35 & 3.09 & 4.89 \\
\hline 77 & 3 & 1 & 95.06 & 3.70 & 1.23 & 2.93 & 4.94 \\
\hline
\end{tabular}

\begin{tabular}{|c|c|c|c|c|c|c|c|}
\hline \multicolumn{8}{|c|}{ Dataset QpLvLs } \\
\hline \multicolumn{3}{|c|}{ Enter Raw Point Count Data Below } & \multicolumn{3}{|c|}{ Output Data } & \multirow{2}{*}{$\begin{array}{l}3.95 \\
x\end{array}$} & \multirow{2}{*}{$\begin{array}{l}3.36 \\
y\end{array}$} \\
\hline Top & Left & Right & Top \% & Left $\%$ & Right $\%$ & & \\
\hline 88 & 7 & 33 & 68.75 & 5.47 & 25.78 & & \\
\hline 101 & 5 & 21 & 79.53 & 3.94 & 16.54 & 3.38 & 4.13 \\
\hline 71 & 1 & 41 & 62.83 & 0.88 & 36.28 & 4.06 & 3.26 \\
\hline 53 & 1 & 49 & 51.46 & 0.97 & 47.57 & 4.40 & 2.67 \\
\hline
\end{tabular}

Table 4: Numerical values are calculated by using Microsoft Excel- based electronic spread sheet proposed by Zahid and Barbeau [13] which is used for calculating intra-ternary provenance fields.

\begin{tabular}{|c|c|c|c|c|c|c|c|}
\hline \multicolumn{8}{|c|}{ Dataset QtFL } \\
\hline \multicolumn{3}{|c|}{ Enter Raw Point Count Data Below } & \multicolumn{3}{|c|}{ Output Data } & \multirow{2}{*}{$\frac{4.05}{x}$} & \multirow{2}{*}{$\begin{array}{r}3.0 \\
y\end{array}$} \\
\hline Top & Left & Right & Top \% & Left $\%$ & Right \% & & \\
\hline 139 & 5 & 59 & 68.64 & 2.22 & 29.14 & & \\
\hline 134 & 8 & 37 & 74.86 & 4.47 & 20.67 & 3.49 & 3.89 \\
\hline 136 & 4 & 64 & 66.67 & 1.96 & 31.37 & 3.88 & 3.46 \\
\hline 30 & 4 & 60 & 31.91 & 4.26 & 63.83 & 4.79 & 1.66 \\
\hline
\end{tabular}

\begin{tabular}{|c|c|c|c|c|c|c|c|c|}
\hline & & & \multicolumn{6}{|c|}{ Dataset QmFLt } \\
\hline \multicolumn{3}{|c|}{ Enter Raw Point Count Data Below } & \multicolumn{3}{|c|}{ Output Data } & \multirow{2}{*}{$\begin{array}{l}4.22 \\
x\end{array}$} & \multirow{2}{*}{\multicolumn{2}{|c|}{$\begin{array}{r}2.53 \\
y\end{array}$}} \\
\hline Top & Left & Right & Top \% & Left $\%$ & Right \% & & & \\
\hline 51 & 5 & 59 & 44.35 & 4.35 & 51.30 & & & \\
\hline 33 & 8 & 37 & 42.31 & 10.26 & 47.44 & 4.12 & 2.20 & \\
\hline 65 & 4 & 64 & 48.87 & 3.01 & 48.12 & 4.35 & 2.54 & \\
\hline 77 & 4 & 60 & 54.61 & 284 & 42.55 & 4.19 & 2.84 & \\
\hline
\end{tabular}


Table 5: Point count data of the Mirpur Unit, Abbottabad Formation

\begin{tabular}{|c|c|c|c|c|c|c|c|c|c|c|c|c|c|}
\hline \multirow{3}{*}{ Slide no } & \multicolumn{4}{|c|}{ Point Count Data } & \multirow[b]{3}{*}{ Igneous } & \multirow{2}{*}{\multicolumn{2}{|c|}{ Rock Fragments }} & \multirow{3}{*}{$\begin{array}{c}\text { Mica } \\
\text { Muscovite }\end{array}$} & \multirow[b]{3}{*}{ Biotite } & \multirow{3}{*}{ Others } & \multirow{3}{*}{$\begin{array}{l}\text { Total } \\
\text { Grains }\end{array}$} & \multirow{3}{*}{ Grain \% } & \multirow{3}{*}{ Matrix \% } \\
\hline & \multicolumn{2}{|c|}{ Quartz } & \multicolumn{2}{|c|}{ Feldspar } & & & & & & & & & \\
\hline & Monocrystalline & Polycrystalline & K-Feldspar & Phagioclase & & Metamorphic & Sedimentary & & & & & & \\
\hline Mp 1 & 101 & 67 & 2 & 3 & 5 & 7 & 11 & 1 & 3 & 7 & 204 & $89.0 \%$ & $11.0 \%$ \\
\hline Mp2 & 93 & 101 & 1 & 7 & 5 & 11 & 14 & 5 & 2 & 6 & 243 & $87.0 \%$ & $17.0 \%$ \\
\hline Mp 3 & 115 & 88 & 3 & 1 & 1 & 13 & 30 & 2 & 2 & 5 & 258 & $85.0 \%$ & $15.0 \%$ \\
\hline $\mathrm{Mp} 4$ & 133 & 53 & 1 & 3 & 1 & 10 & 18 & 3 & 1 & 1 & 223 & $84.0 \%$ & $16.0 \%$ \\
\hline Mp 5 & 85 & 78 & 0 & 1 & 2 & 8 & 9 & 0 & 1 & 8 & 191 & $81.0 \%$ & $19.0 \%$ \\
\hline Mp 6 & 90 & 66 & 0 & 2 & 0 & 5 & 14 & 0 & 2 & 5 & 182 & $80.0 \%$ & $20.0 \%$ \\
\hline Mp 7 & 153 & 84 & 1 & 3 & 1 & 4 & 9 & 0 & 1 & 8 & 263 & $89.0 \%$ & $11.0 \%$ \\
\hline Mp 8 & 116 & 75 & 2 & 0 & 5 & 4 & 20 & 1 & 2 & 10 & 233 & $87.0 \%$ & $13.0 \%$ \\
\hline Mp9 & 143 & 90 & 3 & 8 & 7 & 11 & 25 & 2 & 5 & 9 & 298 & $96.0 \%$ & $4.0 \%$ \\
\hline Mp 10 & 79 & 96 & 2 & 5 & 5 & 4 & 21 & 1 & 7 & 11 & 224 & $91.0 \%$ & $9.0 \%$ \\
\hline
\end{tabular}

Table 6: Numerical values are calculated by using Microsoft Excel- based electronic spread sheet proposed by Zahid and Barbeau [13] which is used for calculating intra-ternary provenance fields

\begin{tabular}{|c|c|c|c|c|c|c|c|}
\hline \multicolumn{8}{|c|}{ Dataset QmPK } \\
\hline \multicolumn{3}{|c|}{ Enter Raw Point Count Data Below } & \multicolumn{3}{|c|}{ Output Data } & \multirow{2}{*}{$\begin{array}{l}2.95 \\
x\end{array}$} & \multirow{2}{*}{$\frac{4.98}{y}$} \\
\hline Top & Left & Right & Top \% & Left $\%$ & Right \% & & \\
\hline 101 & 3 & 2 & 95.28 & 2.83 & 1.89 & 2.97 & 4.95 \\
\hline 93 & 7 & 1 & 92.08 & 6.93 & 0.99 & 2.82 & 4.78 \\
\hline 115 & 1 & 3 & 96.64 & 0.84 & 2.52 & 3.05 & 5.02 \\
\hline 133 & 3 & 1 & 97.08 & 2.19 & 0.73 & 2.96 & 5.04 \\
\hline 85 & 1 & 0 & 98.84 & 1.16 & 0.00 & 2.97 & 5.14 \\
\hline 90 & 2 & 0 & 97.83 & 2.17 & 0.00 & 2.93 & 5.08 \\
\hline 153 & 3 & 1 & 97.45 & 1.91 & 0.64 & 2.96 & 5.06 \\
\hline 116 & 0 & 2 & 98.31 & 0.00 & 1.69 & 3.05 & 5.11 \\
\hline 143 & 8 & 3 & 92.86 & 5.19 & 1.95 & 2.90 & 4.82 \\
\hline 79 & 5 & 2 & 91.86 & 5.81 & 2.33 & 2.90 & 4.77 \\
\hline
\end{tabular}

\begin{tabular}{|c|c|c|c|c|c|c|c|}
\hline \multicolumn{8}{|c|}{ Dataset QpLvLs } \\
\hline \multicolumn{3}{|c|}{ Enter Raw Point Count Data Below } & \multicolumn{3}{|c|}{ Output Data } & \multirow{2}{*}{$\frac{2.29}{x}$} & \multirow{2}{*}{$\begin{array}{c}3.97 \\
y\end{array}$} \\
\hline Top & Left & Right & Top \% & Left $\%$ & Right \% & & \\
\hline 67 & 0 & 11 & 85.90 & 0.00 & 14.10 & 3.42 & 4.46 \\
\hline 101 & 2 & 14 & 86.32 & 1.71 & 11.97 & 3.31 & 4.49 \\
\hline 88 & 0 & 30 & 74.58 & 0.00 & 25.42 & 3.76 & 3.88 \\
\hline 53 & 0 & 18 & 74.65 & 0.00 & 25.35 & 3.76 & 3.88 \\
\hline 78 & 10 & 9 & 80.41 & 10.31 & 9.28 & 2.97 & 4.18 \\
\hline 66 & 0 & 14 & 82.50 & 0.00 & 17.50 & 3.53 & 4.29 \\
\hline 84 & 0 & 9 & 90.32 & 0.00 & 9.68 & 3.29 & 4.69 \\
\hline 75 & 1 & 20 & 78.13 & 1.04 & 20.83 & 3.59 & 4.06 \\
\hline 90 & 2 & 25 & 76.92 & 1.71 & 21.37 & 3.59 & 4.00 \\
\hline 96 & 3 & 21 & 80.00 & 2.50 & 17.50 & 3.45 & 4.16 \\
\hline
\end{tabular}


Table 7: Numerical values are calculated by using Microsoft Excel- based electronic spread sheet proposed by Zahid and Barbeau [13] which is used for calculating intra-ternary provenance fields.

\begin{tabular}{|c|c|c|c|c|c|c|c|}
\hline \multicolumn{8}{|c|}{ Dataset QtFL } \\
\hline \multicolumn{3}{|c|}{ Enter Raw Point Count Data Below } & \multicolumn{3}{|c|}{ Output Data } & \multirow{2}{*}{$\frac{3.31}{x}$} & \multirow{2}{*}{$\begin{array}{r}4.44 \\
y\end{array}$} \\
\hline Top & Left & Right & Top \% & Left $\%$ & Right $\%$ & & \\
\hline 168 & 5 & 23 & 85.71 & 2.55 & 11.73 & 3.28 & 4.45 \\
\hline 194 & 8 & 30 & 83.62 & 3.45 & 12.93 & 3.28 & 4.35 \\
\hline 203 & 4 & 44 & 80.88 & 1.59 & 17.53 & 3.48 & 4.20 \\
\hline 186 & 4 & 29 & 84.93 & 1.83 & 13.24 & 3.34 & 4.41 \\
\hline 163 & 1 & 19 & 89.07 & 0.55 & 10.38 & 3.30 & 4.63 \\
\hline 156 & 2 & 19 & 88.14 & 1.13 & 10.73 & 3.29 & 4.58 \\
\hline 237 & 4 & 14 & 92.94 & 1.57 & 5.49 & 3.12 & 4.83 \\
\hline 191 & 2 & 29 & 86.04 & 0.90 & 13.06 & 3.36 & 4.47 \\
\hline 233 & 11 & 43 & 81.18 & 3.83 & 14.98 & 3.33 & 4.22 \\
\hline 175 & 7 & 30 & 82.55 & 3.30 & 14.15 & 3.33 & 4.29 \\
\hline
\end{tabular}

\begin{tabular}{|c|c|c|c|c|c|c|c|}
\hline \multicolumn{8}{|c|}{ Dataset QmFLt } \\
\hline \multicolumn{3}{|c|}{ Enter Raw Point Count Data Below } & \multicolumn{3}{|c|}{ Output Data } & \multirow{2}{*}{$\begin{array}{c}3.49 \\
\mathrm{x}\end{array}$} & \multirow{2}{*}{$\begin{array}{r}4.01 \\
y\end{array}$} \\
\hline Top & Left & Right & Top \% & Left $\%$ & Right \% & & \\
\hline 101 & 5 & 23 & 78.29 & 3.88 & 17.83 & 3.42 & 4.07 \\
\hline 93 & 8 & 30 & 70.99 & 6.11 & 22.90 & 3.50 & 3.69 \\
\hline 115 & 4 & 44 & 70.55 & 2.45 & 26.99 & 3.74 & 3.67 \\
\hline 133 & 4 & 29 & 80.12 & 2.41 & 17.47 & 3.45 & 4.16 \\
\hline 85 & 1 & 19 & 80.95 & 0.95 & 18.10 & 3.51 & 4.21 \\
\hline 90 & 2 & 19 & 81.08 & 1.80 & 17.12 & 3.46 & 4.21 \\
\hline 153 & 4 & 14 & 89.47 & 2.34 & 8.19 & 3.18 & 4.65 \\
\hline 116 & 2 & 29 & 78.91 & 1.36 & 19.73 & 3.55 & 4.10 \\
\hline 143 & 11 & 43 & 72.59 & 5.58 & 21.83 & 3.49 & 3.77 \\
\hline 79 & 7 & 30 & 68.10 & 6.03 & 25.86 & 3.59 & 3.54 \\
\hline
\end{tabular}

\subsection{Results}

\subsection{Macroscopic features of Abbottabad Formation}

The early Cambrian Abbottabad Formation is comprehensively studied at Khote-di-Qabar section, Hazara region, Pakistan, which constitutes of five distinguished units: 1) Tanaki boulder bed; 2) Sanghargali siltstone/shale; 3) Mohammdagali Dolomite/quartzite; 4) Mirpur sandstone; 5) Sirban dolomite. The lower most unit of Abbottabad Formation is Tanaki Boulder Bed constituting both clast supported and matrix supported conglomerate. It is followed by sand/shale unit which is Sanghargali unit. Dolomite, sandy dolomite and quartzitic sandstone constitute Mohammadagali unit. Mirpur is sandstone unit, with abundant sedimentary structures. Sirban is dolomite and sandy dolomitic unit (Fig. 3). The detailed compositional framework of these units can be described below; 
ISSN: 2576-6732 (Print)

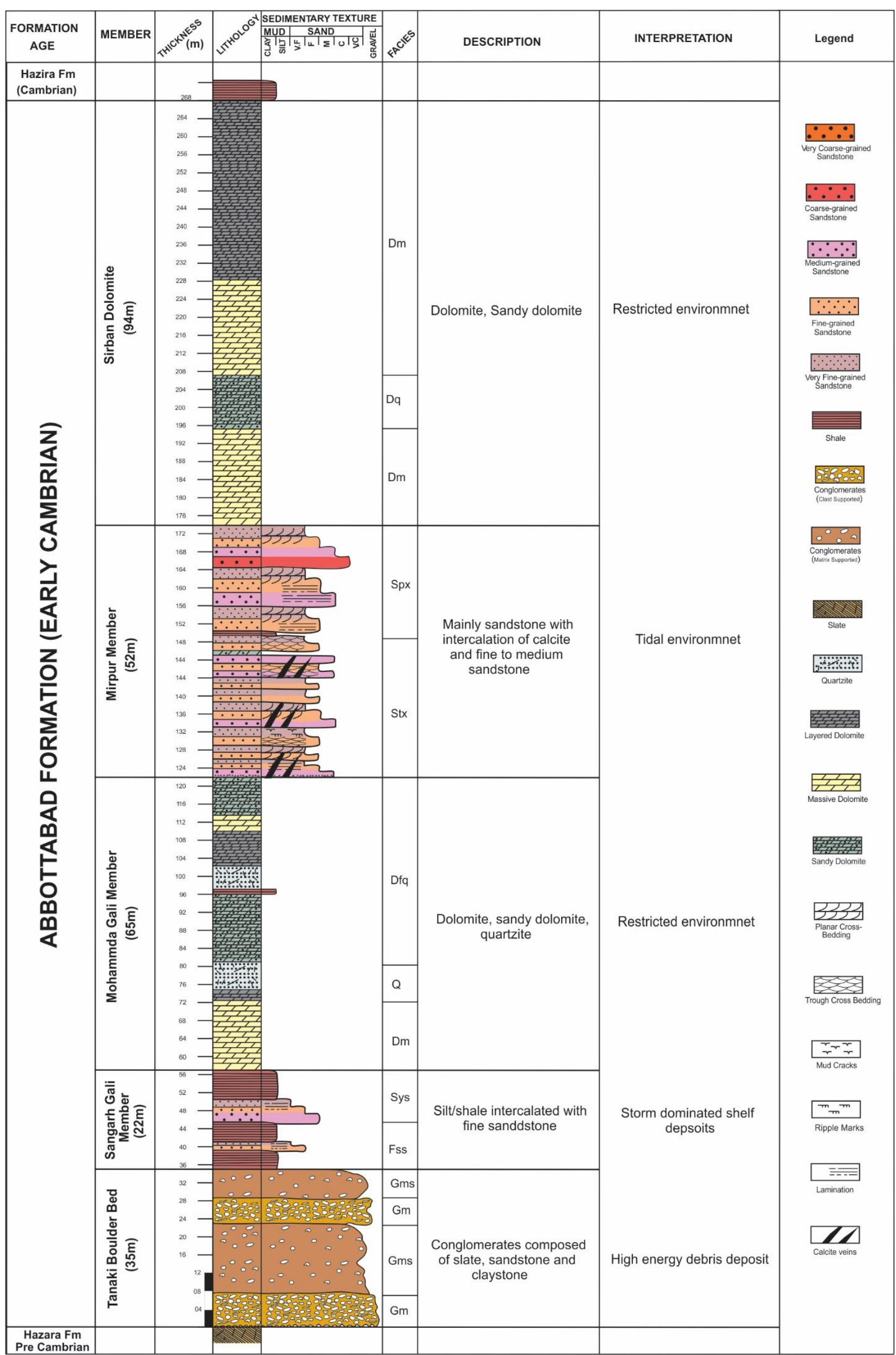

Figure 3: Sedimentary Log of Abbottabad Formation, Khote-di-Qabar Section, Hazara Area, Pakistan 


\section{a) Clast Supported Conglomerate (Gm)}

Description: This facies is present in alternate cycle with matrix supported conglomerate with one unit at the base and one at top of first matrix supported conglomerate (Fig. 3). Clast size ranges from $5 \mathrm{~cm}$ to $7 \mathrm{~cm}$ with maximum particle size of $10 \mathrm{~cm}$ (Fig. 4A). The clasts are mostly of claystone and sandstone in origin, with few slate clasts are also present. Matrix is clay with minor quantity of sandstone. The clasts are mostly sub-rounded and very few angular clasts are reported and their edges are also worn off.

Interpretations: Rounded or equant clasts show the larger transporting distance and larger size of clasts indicates that this facies was deposited by the high energy transporting agent [11].

\section{b) Matrix Supported Conglomerate (Gms)}

Description: This is alternate unit with clast supported conglomerate, matrix is clayey in nature, clasts are of small size ranging from $2 \mathrm{~cm}$ to $5 \mathrm{~cm}$, with very few larger clasts of $8 \mathrm{~cm}$ (Fig. 4B). Clasts present are of mostly claystone lithology. Some small sand beds in the unit are also identified which range in size from $4-10 \mathrm{~cm}$ (Fig. 4B), sand is medium to coarse grained.

Interpretations: Matrix supported gravel beds are deposited in fluvial settings and are characteristics of debris flow deposits [14].
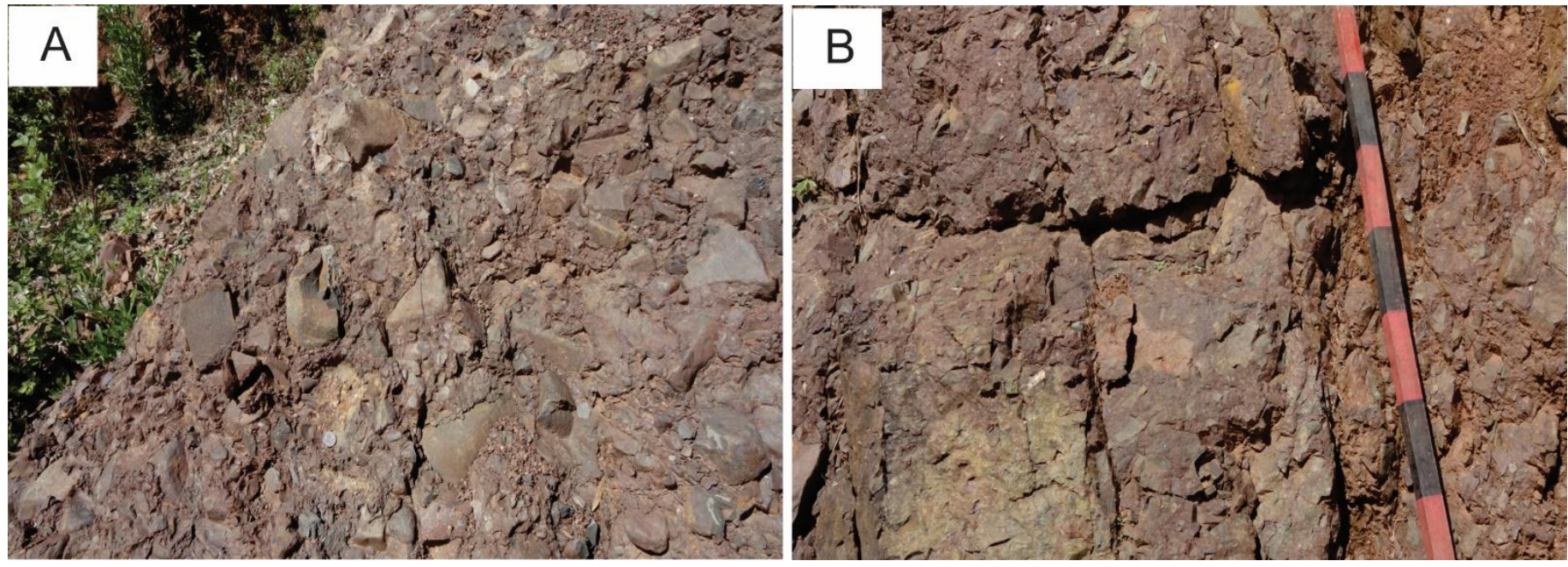

Figure 4: Tanaki Boulder Bed Unit (Abbottabad Formation) (A) Clast Supported Conglomerate (B) Matrix Supported Conglomerate

\subsubsection{Lithofacies Analysis of Sanghargali Shale/silt unit}

Sanghargali consists of shale, siltstone unit and two lithofacies are identified (Fig. 5):

\section{a) Alternate sandstone and siltstone unit (Fss)}

Description: This unit comprises of alternate shale and siltstone unit, thin bedding to laminations are present in this unit (Fig. 5A). The color of shale units are purple to maroon with reddish tinge, the siltstone is of light grey to reddish grey in color.

Interpretations: The alternate shale and siltstone is mostly deposited in tidal environment, so it is deposited in strom dominated shelf succession [15].

\section{b) Fine sandstone shale unit (Svs)}

Description: This unit comprises of $1 \mathrm{~m}$ fine sandstone unit with massive shale beds (Fig. 5B). Shale beds are thinly laminated and sandstone is also very fine grained and laminations are present in it.

Interpretations: Fine sandstone, with no internal structure and abundant amount of shale and siltstone is characteristics of shelf deposits [15].
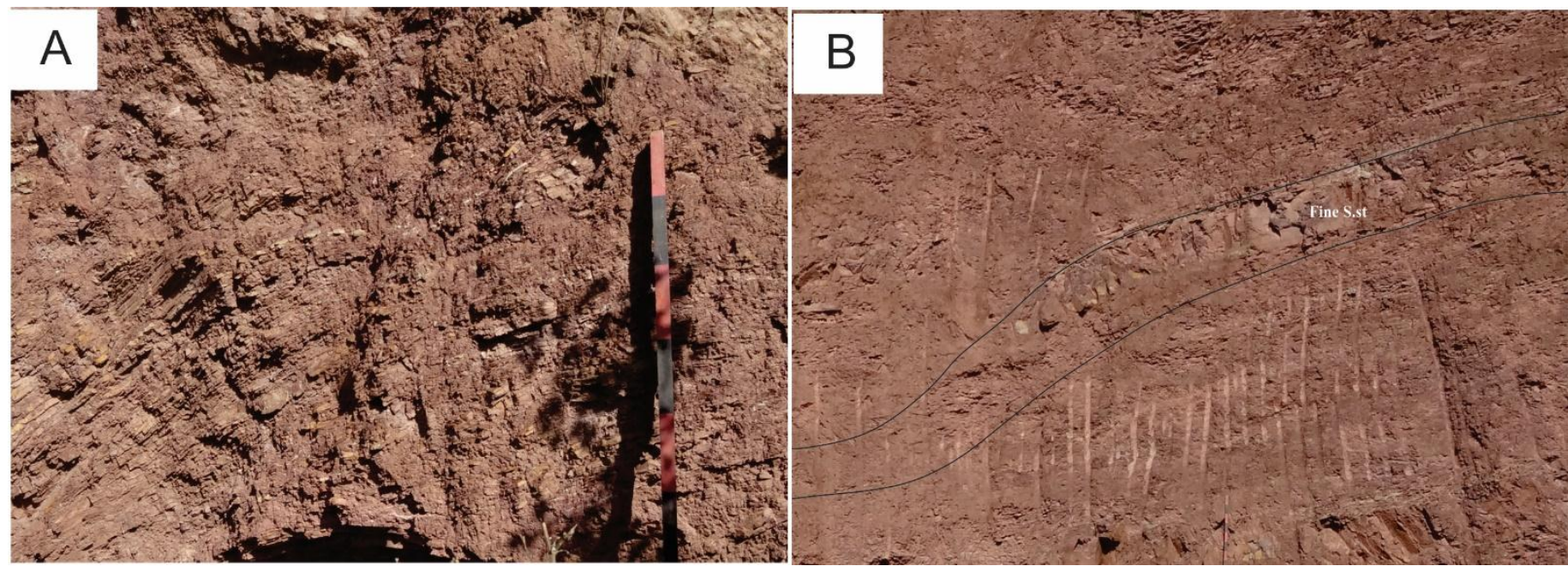

Figure 5: Sanghargali Sand/Shale Unit (Abbottabad Formation): (A) Shale with alternate layers of siltstone; (B) Shale with fine sandstone bed

\subsubsection{Lithofacies Analysis of Mohammdagali Dolomite and Quartzitic Unit}

This unit comprises of massive dolomite, thinly bedded- dolomite and sandy dolomite, and quartzite (Fig. 6). The lithofacies identified are given as:

\section{a) Massive Dolomite (Dm):}

Description: The dolomite is light pink to grey in color, bedding is essentially missing (Fig. 6A). Dolomite is very hard in nature. This type of dolomite gradually changes into sandy and quartzitic dolomite.

Interpretations: Massive dolomite facies is deposited in restricted and shallow sub-tidal environment, as there is no fauna which indicates restricted 
environment and also lack of sub-aerial features indicates restricted marine conditions [16].

\section{b) Sandy Dolomite (Dfq):}

Description: The dolomite is of whitish to pinkish in color and sandy in nature. The dolomite is present in alteration with quartzite layers (Fig. 6B).

Interpretations: Presence of sand in restricted dolomitic unit indicates deposition in platform area with little supply of sand.

\section{c) Quartzite (Q):}

Description: The quartzite is of grey to light grey in color. The lithology is pure quartz arenite. The bedding is thin to medium bedded and present as 0.5 to 1 m beds.

Interpretations: Presence of quartzite suggests restricted shallow subtidal environment of deposition indicated by stratigraphic position below tidal flat facies [16].
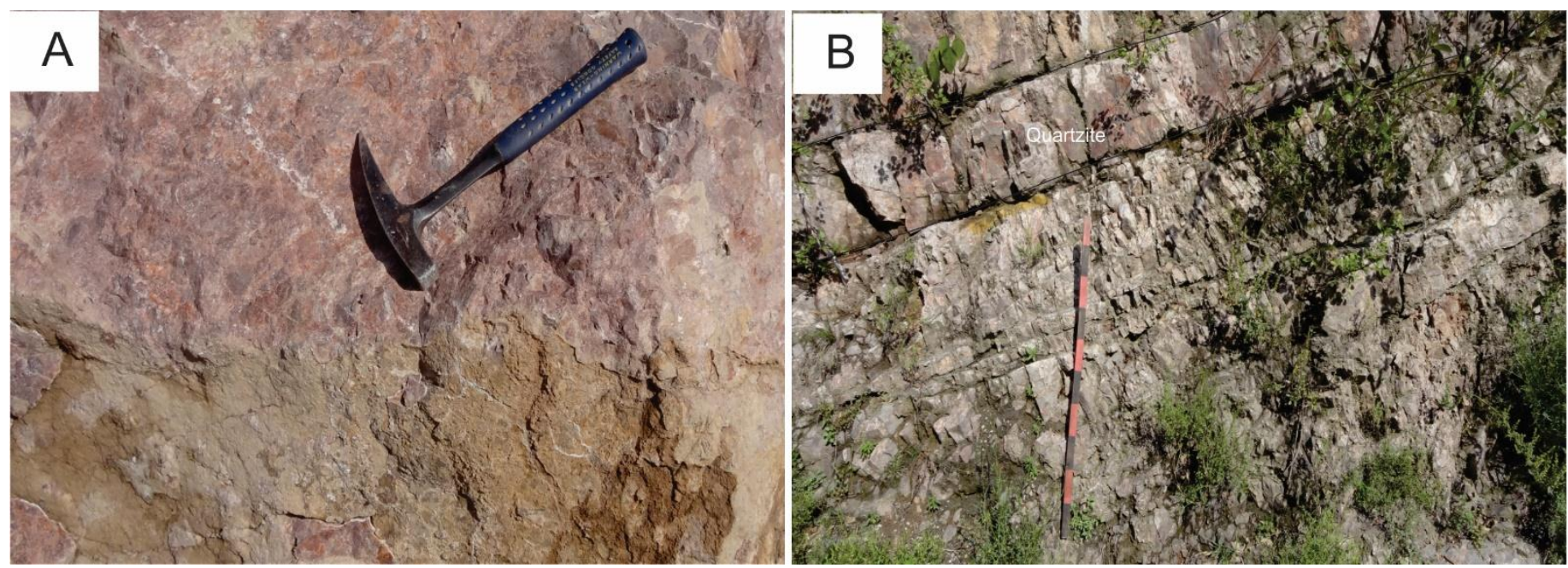

Figure 6: Mohammdagali Dolomite Unit (Abbottabad Formation): (A) Massive Dolomite; (B) Quartzite Bed between sandy dolomite beds

\subsubsection{Lithofacies Analysis of Mirpur Sandstone Unit}

This unit comprises of fine to medium sandstone, sedimentary structures predominantly trough cross bedding, planar cross bedding, ripple marks, laminations and calcite veins are cross cutting the beds (Fig. 7). The lower contact of the Mirpur Unit is gradational/transitional with the Mohammdagali Dolomite Unit and it also has gradational contact with overlying Sirban Dolomite unit. Two distinguishable facies are identified, which are discussed below:

\section{a) Fine to medium trough cross bedded sandstone (Stx):}

Description: This is basal facies, at the contact small scale conglomerate marks, unconformable succession. The sandstone unit is fine to medium grained, sedimentary structures present are laminations, ripple marks, bioturbations and predominantly trough cross bedded sandstone. Calcite veins are crosscutting the beds. These veins are interconnected and discontinuous and vary in thickness from 1 to $10 \mathrm{~cm}$ (Fig. 7a, b).

Interpretations: Trough bedding is commonly developed in fluvial or tidal environment, but stratigraphic position suggests tidal environment with little influence of carbonate [17].

\section{b) Medium, planar cross bedded sandstone (Spx):}

Descriptions: This facies include planar cross-bedded sandstone, the basal part of facies are thinly laminated. The calcite is present on the bedding in the form of caliche, the facies gradually changes into massive dolomite (Fig. 7c, d).

Interpretations: On the basis of stratigraphic position, planar cross bedding is developed in tidal environment and presence of calcite indicates influx of carbonate is steadily increasing [18]. 

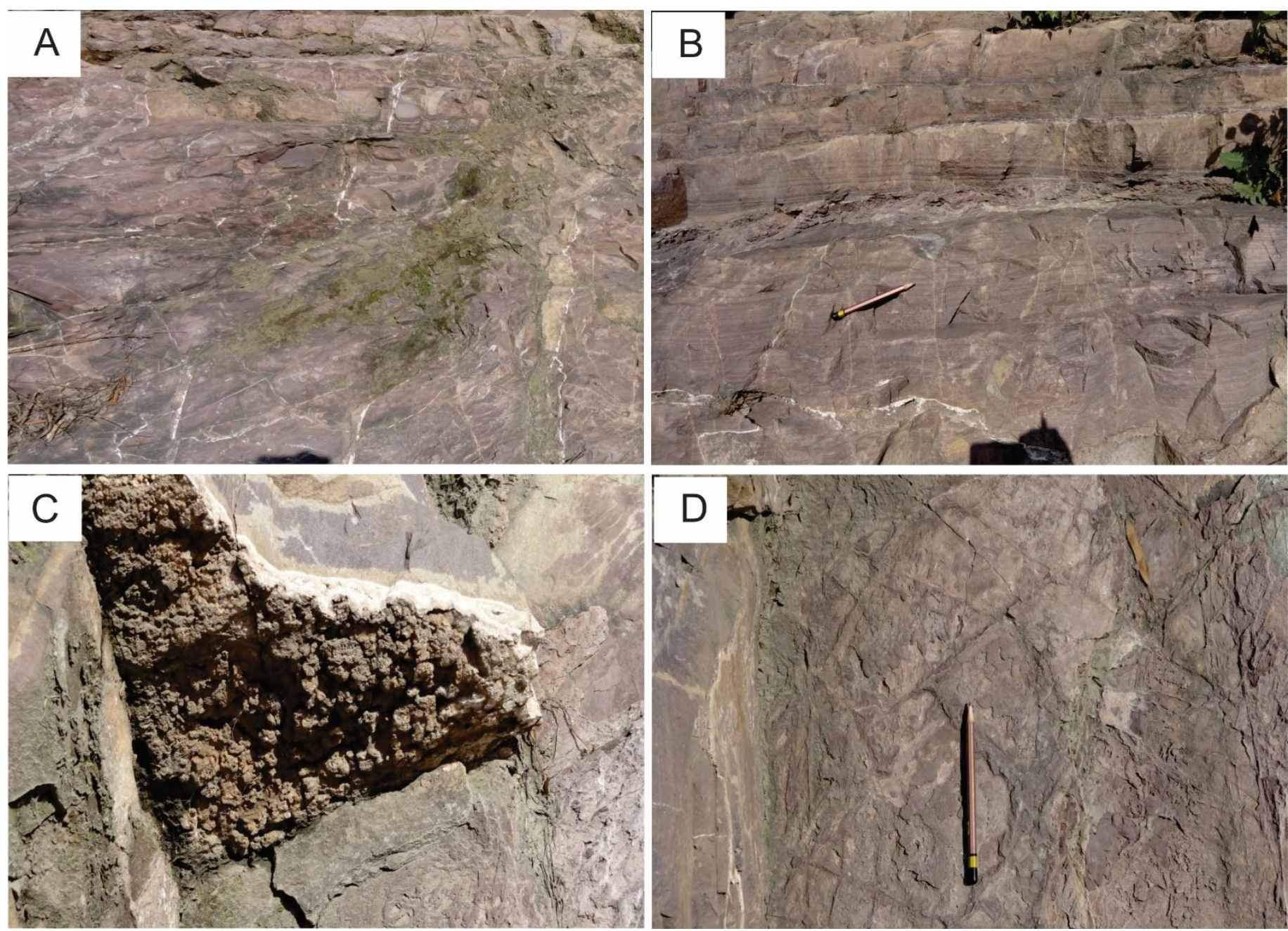

Figure 7: Mirpur Sandstone (Abbottabad Formation) (A) Trough Cross Bedded Sandstone with calcite veins cross-cutting. (B) Planar Cross Bedded Sandstone. (C) Calcite on the surface of fine sandstone (D) Bioturbation surface on top of planar cross-bedded sandstone

\subsubsection{Lithofacies Analysis of Sirban Dolomite Unit}

The dolomite present in the section is mostly pure in composition, with middle part is sandy in composition. Bedding at the base is massive then gradually changes into thin bedded dolomite. Two lithofacies are identified (Fig. 8):

\section{a) Massive Dolomite (Dm):}

Description: This type of facies is abundant in the sections. The dolomite present is of white color, chop board weathering is present on the surface. The bedding is not clear.

Interpretations: Massive dolomite facies is deposited in restricted and shallow sub-tidal environment, as there is no fauna which indicates restricted environment and also lack of sub-aerial features indicates restricted marine conditions [16].

\section{b) Sandy Dolomite (Dq):}

Description: This type of dolomite is present in the form of thin to medium bedding, the dolomite is of whitish to grey in color, and is moderately hard. Interpretations: Presence of sand in restricted dolomitic unit indicates deposition in platform area with little supply of sand.
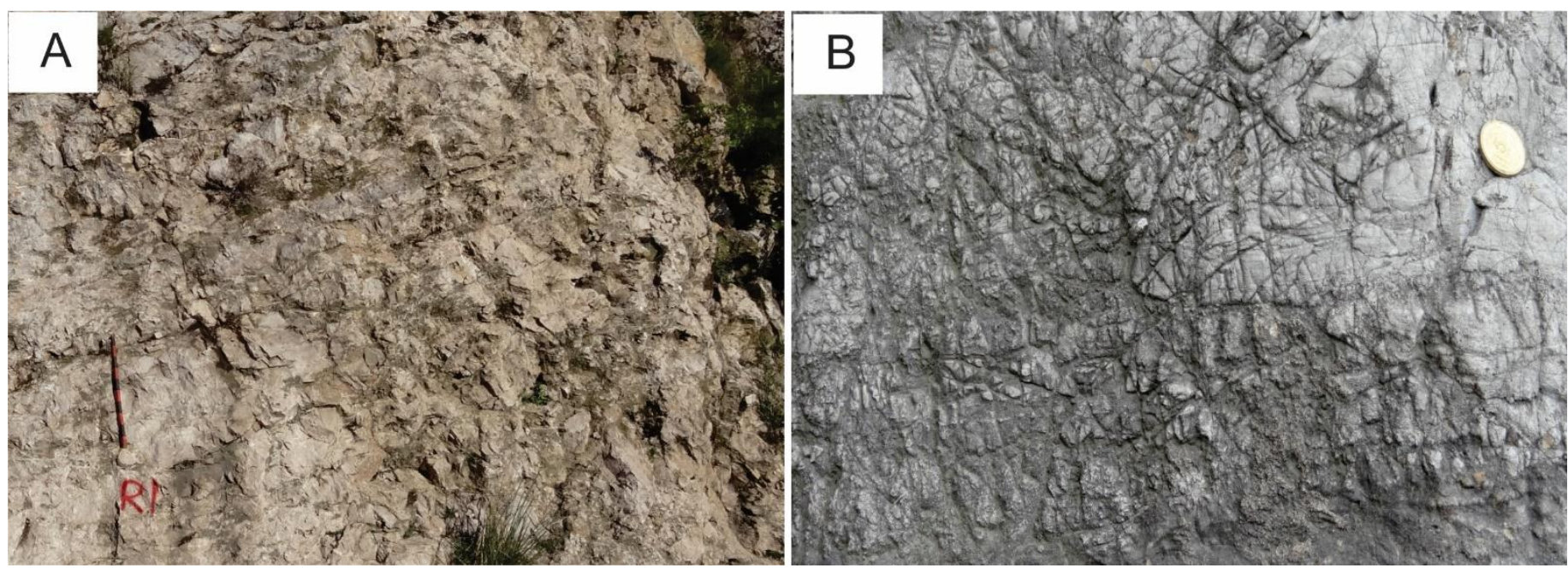

Figure 8: Sirban Dolomite (Abbottabad Formation); (A) Massive Dolomite (B) Chop Board Weathering in Sirban Dolomite. 


\subsection{Microscopic features of Abbottabad Formation}

Petrographic analysis of Sanghargali Sand/shale unit and Mirpur unit of the early Cambrian Abbottabad Formation at Khote-di-Qabar section, Hazara region, Pakistan display the various constitute which is useful to interpret its provenance. The detail microscopic descriptions of thin section sample of these units are given below;

\subsubsection{Petrographic Analysis of Sanghargali Sand/shale unit}

Sandstone of Sanghargali unit is taken in order to find provenance of the unit. Sandstone is dominantly composed of quartz (Figure 9a, c-e) with few rock fragments (Fig. 9b). Quartz grains are polycrystalline with minor quantities of monocrystalline grains. Rock fragments are also present, most of rock fragments are sedimentary and metamorphic with few igneous lithic fragments, and feldspar is very rare. Some mica is also present. Grain size of quartz ranging from fine to very fine and their contact with other grains are mostly pointed with few sutured contacts as well. Grains are mostly angular to sub angular sub rounded grains are sparse. Sorting is moderate to poor. Undulatory extinction is shown by quartz grains by rotating the stage, quartz grains change their color white to dark grey to black. Feldspar is present in small quantity both potash and plagioclase feldspars are present. Moreover, clay is present in the matrix and cement is dominantly hematite and calcite (Fig. 9a-f).
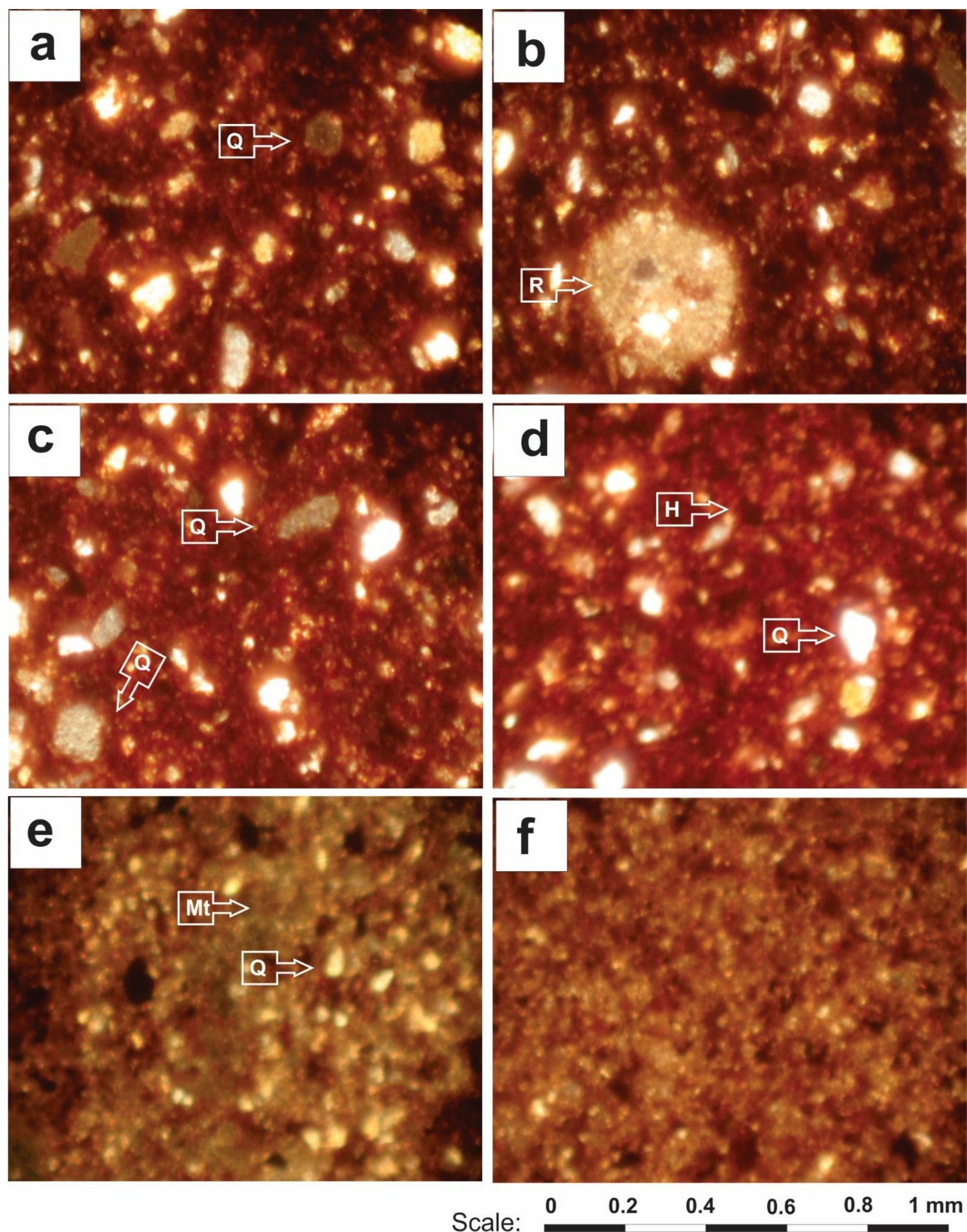

Figure 9: Photomicrographs of framework grains including quartz, feldspar and rock fragments in the Abbottabad Formation (Sanghargali unit) Hazara area, Pakistan. $\mathrm{Q}=$ Quartz, $\mathrm{R}=$ Rock Fragments, $\mathrm{Mt}=$ Matrix and $\mathrm{H}=$ Heamatite 
4.2.2. Petrographic analysis of Mirpur unit

Petrographic analysis of sandstone sample is carried out to find composition and texture of the rock. Sandstone unit is dominantly composed of quartz with few rock fragments. Quartz is the dominant lithology (Figs. 10a-f, 11a-f). Quatrz grains are monocrystalline and polycrystalline. Quartz grains are easily recognized in cross nicols, under polarizing microscope. Texture of the quartz grains shows moderate to poor sorting and size ranges from fine to medium grained. Contact relationships of the grains show sutured and pointed contacts. Quartz is recognized by its distinctive undulatory extinction. Rock fragments are also present (Figs. 10a, 11b, c), most of rock fragments are sedimentary and metamorphic with few igneous lithic fragments, and feldspar is very rare. Some mica is also present (Fig. 10a). Feldspar is dominantly alkali feldspar with minor plagioclase. Moreover, heavy minerals like magnetite and glauconite are present in small amount. The clay and mica is present in the matrix (Figs. 10a, d-f, 11e, f). Major cementing material is calcite (Figs. 10a-f \& 11a-f).
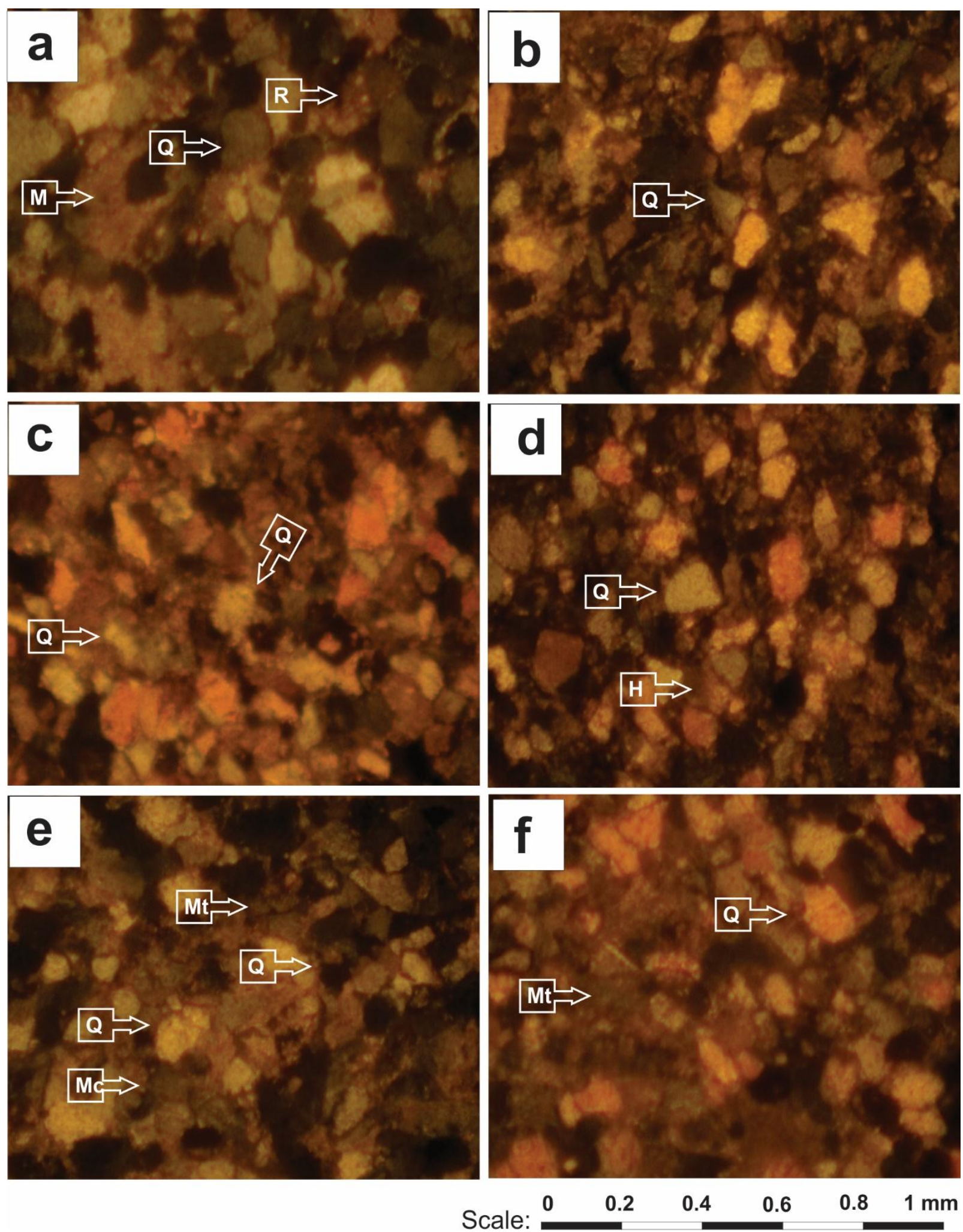

Figure 10: Photomicrographs of framework grains including quartz, feldspar and rock fragments in the Abbottabad Formation (Mirpur unit) Hazara area, Pakistan. $\mathrm{Q}=$ Quartz, $\mathrm{P}=$ Plagioclase, $\mathrm{Mc}=$ Microcline, $\mathrm{M}=$ Mica, $\mathrm{R}=$ Rock Fragments, $\mathrm{Mt}=$ Matrix and $\mathrm{H}=$ Heamatite 

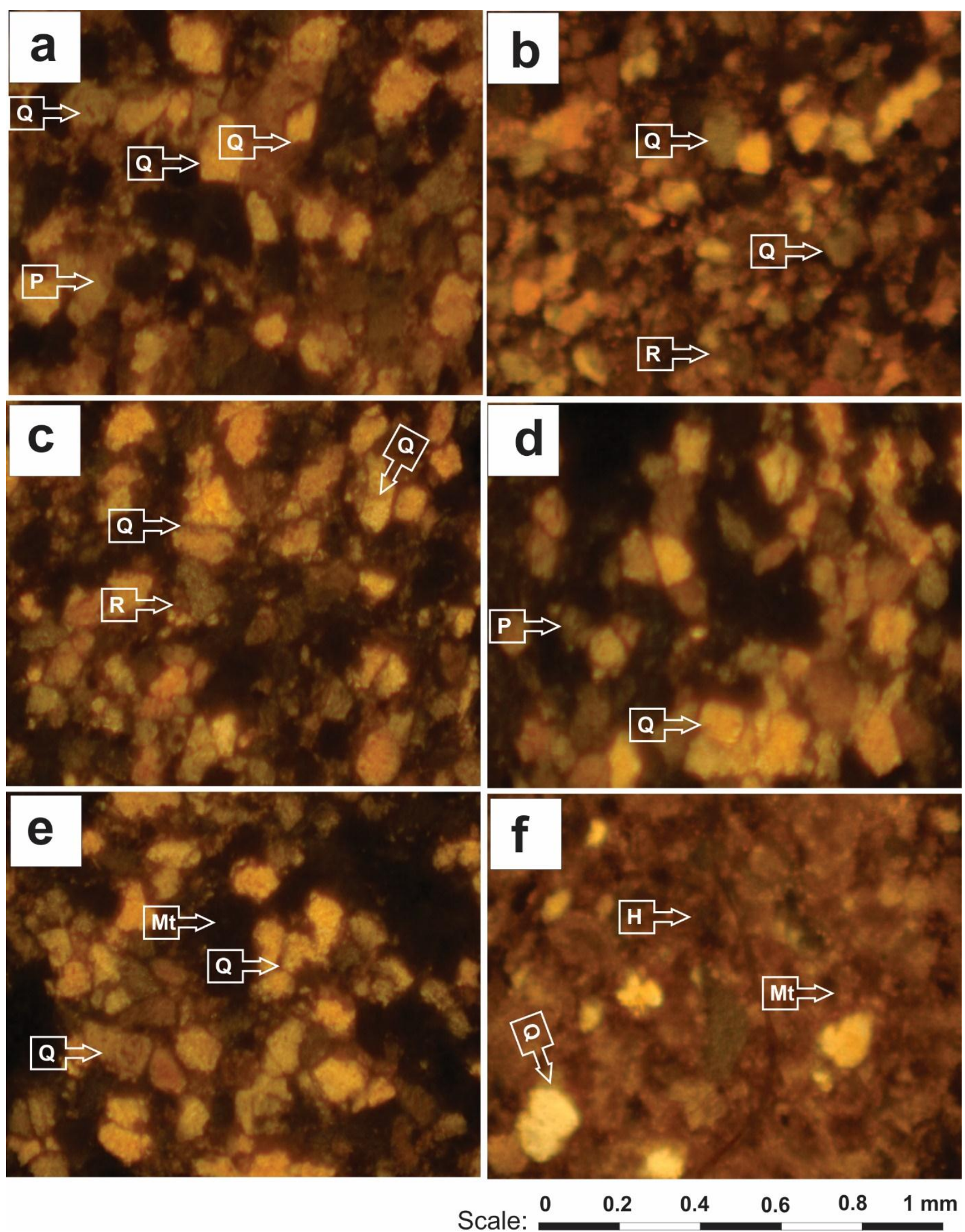

Figure 11: Photomicrographs of framework grains including quartz, feldspar and rock fragments in the Abbottabad Formation (Mirpur Unit) Hazara area, Pakistan. $\mathrm{Q}=\mathrm{Quartz}, \mathrm{P}=$ Plagioclase, $\mathrm{Mc}=$ Microcline, $\mathrm{M}=$ Mica, $\mathrm{R}=$ Rock Fragments, $\mathrm{Mt}=$ Matrix and $\mathrm{H}=$ Heamatite

\subsection{Discussion}

\subsection{Provenance of Tanaki boulder bed}

Tanaki boulder bed comprises of conglomeratic/brecciated beds which are clasts as well as matrix supported. The clast are moderately rounded to angular and are of mixed origin, mostly derived from the rocks which are present below it i.e. sandstone, claystone, slates etc. Matrix is clayey in origin and in some part has sandy matrix. The point count analysis of selected area shows total 93 clasts, out of them 51 sedimentary, 37 metamorphic and 5 igneous clasts (Fig. 12). The percentages of these clasts are $54.8 \%, 39.9 \%$ and $5.4 \%$ respectively. Ternary plot has confirmed the dominant lithology to be sedimentary and metamorphic. Furthermore, this process gives different sedimentary sublithologies. Sandstone clasts are 9, shale/siltstone clasts are 7 and claystone clasts are 33. These can also be expressed in percentages, i.e. $17.6 \%$ sandstone, $13.7 \%$ shale/siltstone, $64.7 \%$ claystone (Figs. 12 \& 13). 

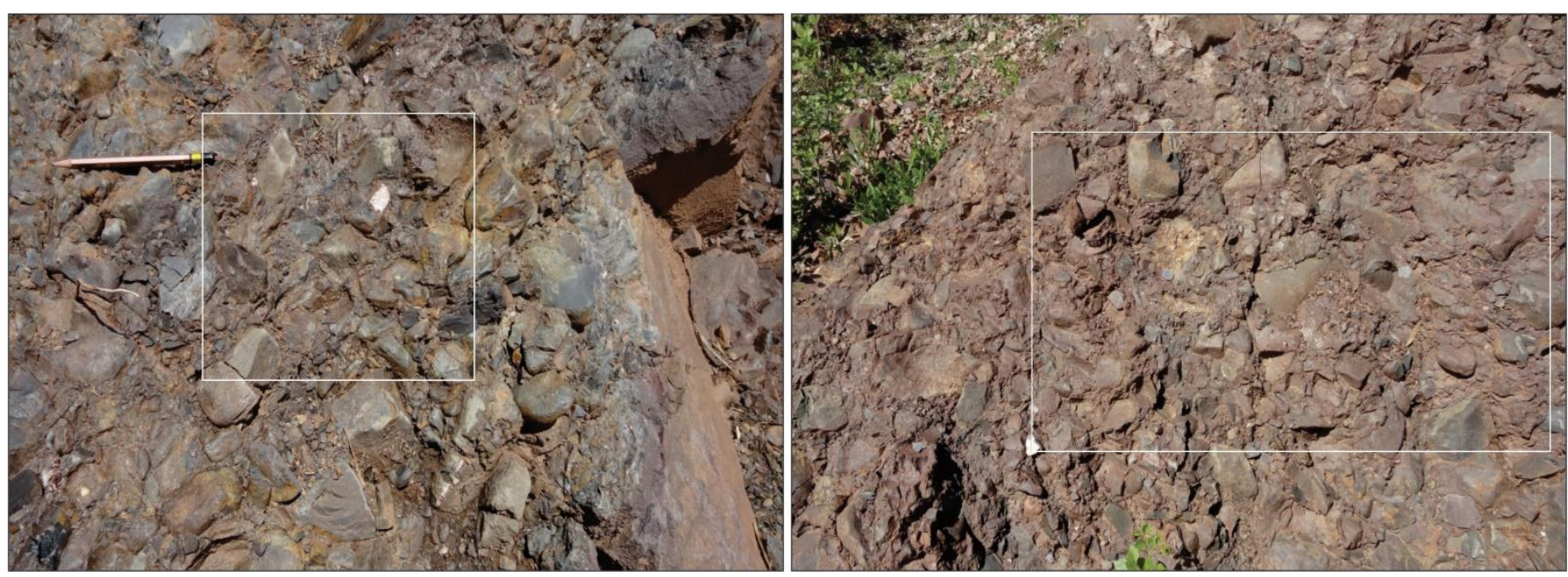

Figure 12: Area marked for clast count method in Tanaki Boulder Bed, Abbottabad Formation

\section{Igneous}

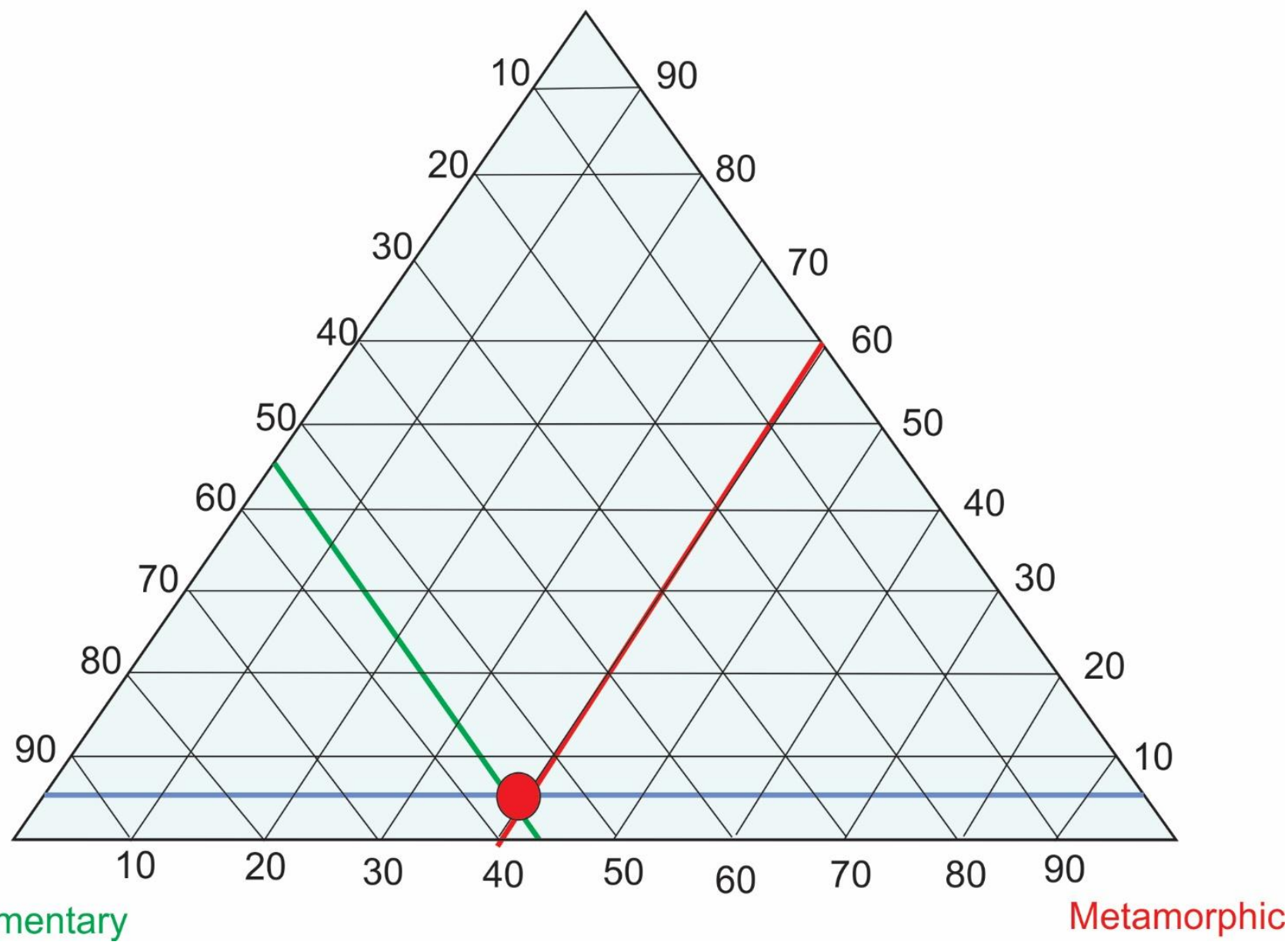

\section{Sedimentary}

Figure 13: Ternary diagram showing the percentage of different types of clasts of the Abbottabad Formation (Tanaki Boulder Bed) [11]

The properties of these clasts such as size, shape and roundness of the coarse clasts are easily to measure but face difficult to those which are cemented and lithified [11].

1. Gravity flow deposits show a positive correlation between MPS vs. BTh, this is not the case for stream deposit.

2. The absence of correlation between MPS vs. BTh is suggested to be due to erosion and to 'grain-by-grain' mode of deposition in fluvial gravel/conglomerate beds.

3. Measurement of maximum particle size (MPS) reflects competency of flows.

4. Bed thickness measurement (BTh) reflects capacity of flow.

5. The linear regression line of the plot (MPS vs. BTh) passes through the origin it represents a cohesionless debris flow of either sub-areal or sub aqueous nature. If it does not but intersects at some point on the ordinate emplacement as sub-areal cohesive debris flow is suggested (Fig. 14). 


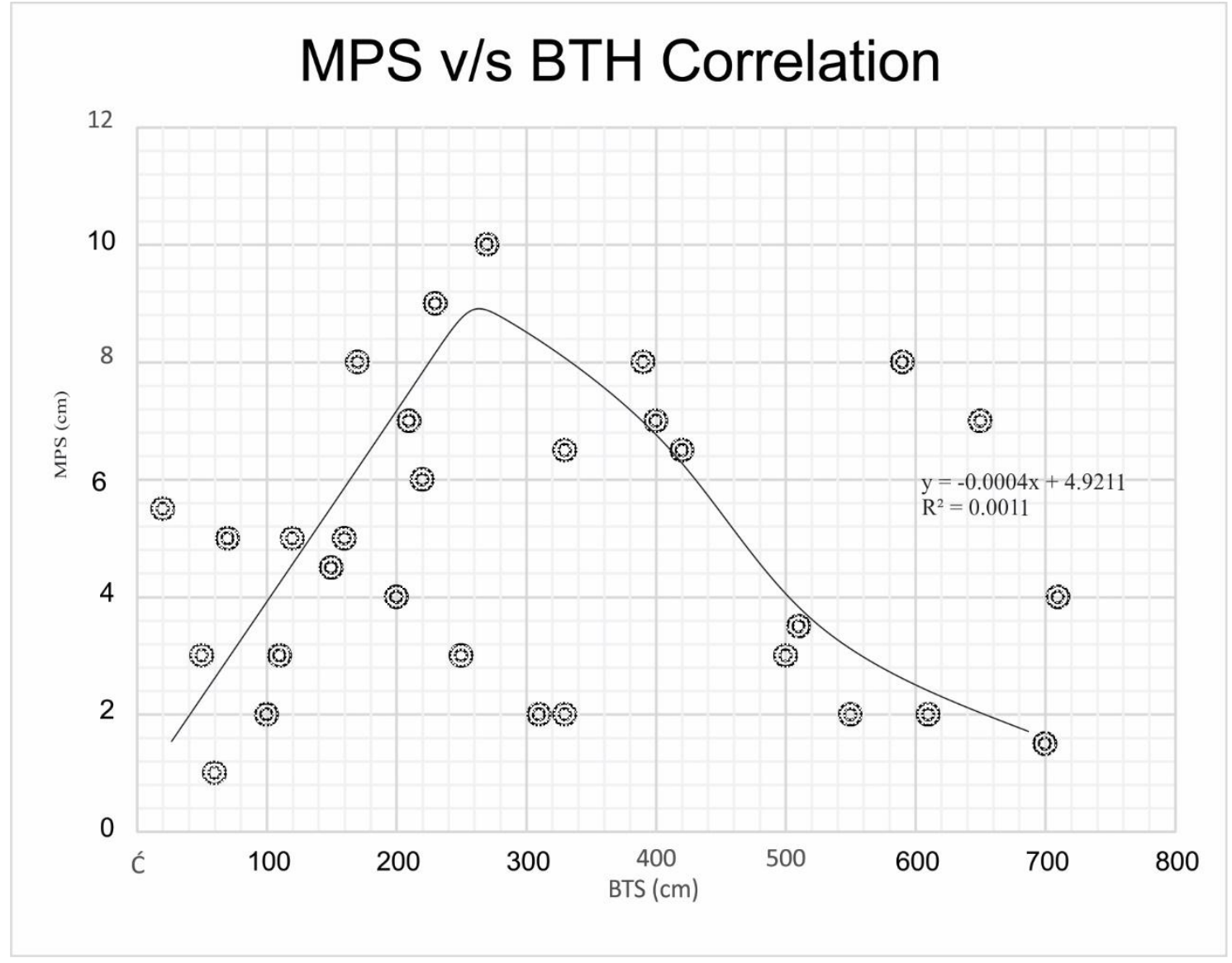

Figure 14: Regression line from MPS/BTh data of the Abbottabad Formation (Tanaki Boulder Bed)

Roundness of the clasts is estimated with the help of silhouette chart for pebbles as proposed by Krumbein [19] and Roussillon et al. [20] and clarifies two points including; 1) well-worn rounded clasts indicate long history of transport before their final burial. 2) Clasts with angular edges and corners indicate local derivation and short history of transport before their final burial. Furthermore, conglomerates and breccias are differentiated on the basis of roundness of the clasts.

These calculations demonstrate that dominant lithologies of Tanaki boulder bed belong to sedimentary and metamorphic sources in which more common sedimentary clasts are claystone and sandstone. This data clarifies that the sediments are derived from nearby sources. Additionally, MPS/BTH data shows no correlation which is the case for fluvial/stream deposits (Fig. 14). Regression line depicts no correlation, so Tanaki Boulder Beds are stream deposits.

\subsection{Provenance of Sanghargali Unit}

The mineralogy and genetic composition of sandstone is governed by lithology of parent rock. The terrigenous clastic sediments are derived from parent rock, which travel towards the basin by different medium including water, air and ice etc. The mineralogy and climate of the source rock affect the lithology of sediments. Additionally, tectonic and weathering are major controlling elements that play role in genesis of specific type of sediments. Weathering is governed by climate of provenance areas. In humid areas, intense chemical weathering occurs and unstable minerals like feldspars are destroyed and stable minerals like quartz survive. Tectonic controls height in turn relief of the area. In high topographic areas sediments are transported rapidly so there is very little time for weathering to take place. There is strong relationship between sandstone provenance and its relationship with tectonic setting and mineralogy of rock [13].

Main detrital components of the Sanghargali unit are polycrystalline quartz, lithic fragments, very rare feldspar and few accessory minerals like mica and hematite etc (Fig. 15). On the basis of Folk classification, the Sanghargali unit is litharenite. Dominant quartz type is polycrystalline quartz which is about $60 \%$ of total quartz, the origin of polycrystalline quartz is mostly metamorphic rocks with few granitic rocks etc. Furthermore, plagioclase is abundant among the feldspars and its origin is plutonic/granitic rocks. Therefore, most suitable location for the origin of sediments of Sanghargali unit is Aravali and Malani Ranges located in the South. 

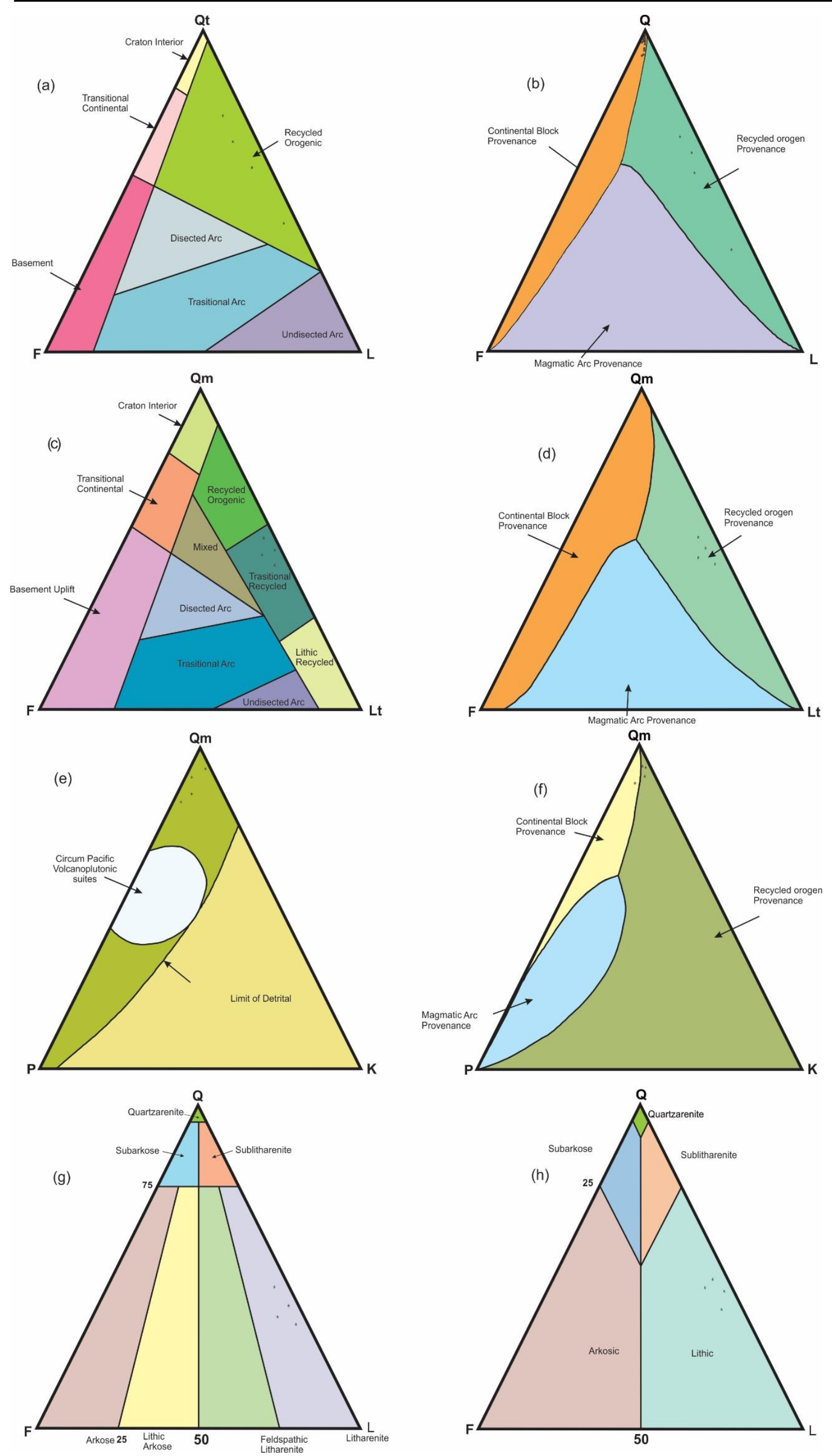
Figure 15: Diagrams showing the ternary plots for the provenance of Sanghargali unit, Abbottabad Formation by using numerical values from table 3 and 4 (a) Dickinson's [21] QtFL (b) Weltje's [22] QFL (c) Dickinson's [21] QmFLt (d) Weltje's [22] QmFLt (e) Dickinson's [21] QmPK (f) Weltje's [22] QmPK (g) Folk's [23] (h) Dott's [24]

\subsection{Provenance of Mirpur Unit}

For provenance analysis of Mirpur Sandstone unit of Abbottabad Foramtion similar electronic spread sheet is used in which point count data is entered and different ternary plots were made giving specific information (Fig. 16). Major framework grains of Mirpur Sandstone consist of quartz (Monocrystalline + polycrystalline), rock fragments, few feldspar grains and some heavy minerals like magnetite and glauconite. On the basis of Folk Classification Mirpur Unit (Abbottabad Formation) is sublitharenite and in Dott Classification scheme it also comes out to be sublitharenite. Mainly monocrystalline quartz is abundant which is present in plutonic rocks i.e. granite and feldspar is dominantly albite which is mostly derived from rocks like granite and gneiss. Therefore, above arguments demonstrate that parent rock must be some granitic rock and paleogeogrphy suggests that sediments travelled from south toward north, so the suitable geological locations are Aravali and Malani Ranges. 

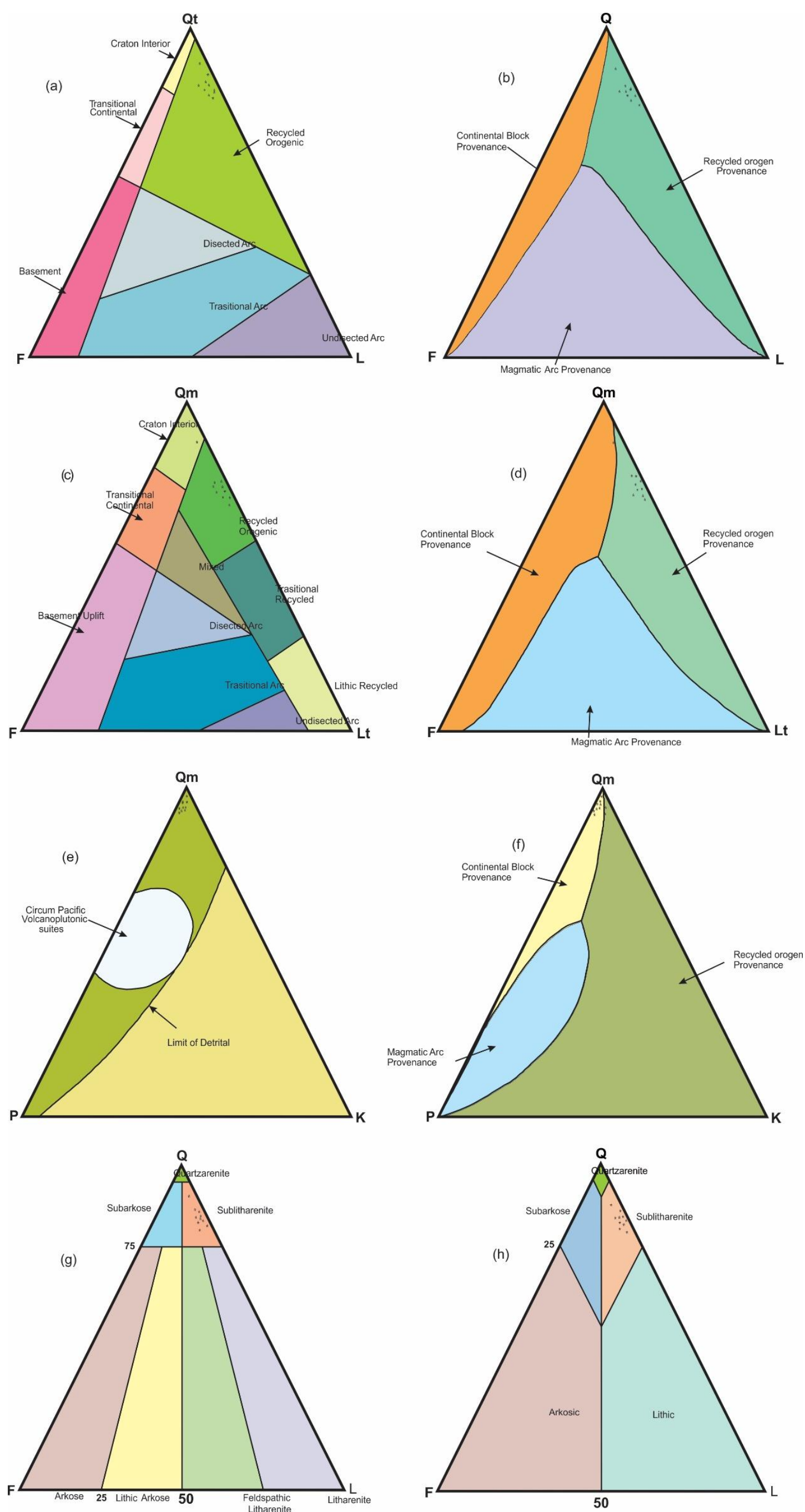
Figure 16: Diagrams showing the ternary plots for the provenance of Mirpur unit, Abbottabad Formation by using numerical values from table 6 and 7 (a) Dickinson's [21] QtFL (b) Weltje's [22] QFL (c) Dickinson's [21] QmFLt (d) Weltje's [22] QmFLt (e) Dickinson's [21] QmPK (f) Weltje's [22] QmPK (g) Folk's [23] (h) Dott's [24]

\subsection{Conclusions}

Abbottabad Formation is deposited in the Southern Sedimentary Region of Hazara Area that forms unconformable relationship at the base with PreCambrian Hazara Formation, which are predominantly slates in the study area and gradational upper contact with Hazira Formation on the basis of, Hyolithes fauna. Abbottabad Formation is group is sedimentary packages including clastic and carbonate part deposited under varying depositional setting. Predominantly basal part is clastic and most of upper part is carbonate. Lower most sedimentary unit is Tanaki Boulder Bed, is conglomerate deposited under fluvial conditions. The Sanghargali Unit is a next one that composed of shale, silt unit with subordinate sandstone is reddish to purple in color and microscopically the lithology of sandstone is litharenite along with dominant detrital components are polycrystalline quartz and rock fragments. This unit is deposited in tidal strom dominated environment. The middle unit (Mohammdagali) is dolomite and quartzitic in composition deposited under restricted subtidal environment. The Mirpur Sandstone unit, macroscopically depicting majorly sandstone with minor amount of calcite and microscopically is sublitharenite, deposited in tidal environment with little influx of calcite. The upper most unit (Sirban Dolomite) is also thick dolomite unit, at places sandy deposited in tidal environment with little influx of clastic material. Furthermore, the petrographic study clarify that provenance of sediments of Sanghargali unit is Aravali and Malani Ranges located in the South. Similarly, the presence of few granitic rock and paleogeogrphical setting of Mirpur Sandstone unit also demonstrate that sediments travelled from south toward north, so the suitable geological location are Aravali and Malani Ranges.

\section{Acknowledgement}

The present work is a part of MPhil thesis of Inam ur Rahim which was completed in the University of the Punjab. The Authors are highly thankful to Dr. Muhammad Riaz (China University of Geosciences, Beijing), who actively participated in the preparation and acceptance of the manuscript.

\section{Conflict of Interest:}

Financial support from University of the Punjab, Lahore, Pakistan. There is no conflict of interest among the authors.

\section{References:}

[1] P. Mark, C.M. Ali, "The geology of the Abbottabad area with special reference to the Infra-Trias. Geo Bull Univ Punjab. 2(1961), 47-56[2] C.M. Ali, The Stratigraphy of South Western Tanawal Area, Hazara, West Pakistan”, Geo Bull Univ Punjab, vol. 2, pp. 31-38, 1962.

[2] J.A. Calkins, T.W. Offield, S.K.N Abdullah, S.T. Ali, “Geology of the southern Himalaya in Hazara, Pakistan and adjacent areas”, U.S. Geol. Surv., Prof. Pap., vol. 716, pp. 29, 1975.

[3] M. Qasim, M.A. Khan, M. Haneef, "Stratigraphic characterization of the Early Cambrian Abbottabad Formation in the Sherwan area, Hazara region, N Pakistan: Implications for Early Paleozoic stratigraphic correlation in NW Himalayas, Pakistan”, J Him Earth Sci, vol. 47, no. 1, pp. 25-40, 2014.

[4] G. Khan, M. Alam, J. Akhter, "Geotechnical properties of Cambrian Dolomite, Abbottabad Formation, Hazara-Kashmir Syntaxis an Azad Kashmir, Pakistan. 3rd International Conference on Emerging Trends in Engineering”, Management and Sciences (3rd ICETEMS 2018), 10th- 11th November 2018, At Karakoram International University, Gilgit-Pakistan.

[5] C.M.A. Powell, "A speculative history of Pakistan and surrounding: some constraints from Indian Ocean, in: A. Farah, K.A. DeJong, (Eds.)”, Geodynamics of Pakistan, 1979.

[6] C.N. Izzat, "Variation in thrust front geometry across the Potwar Plateau and Hazara/Kalachitta Hill Ranges, Northern Pakistan", Ph.D Thesis, Imperia College of Science, Technology and Medicine, London,1993.

[7] M.A. Latif, "Explanatory notes on the geology of Southeastern Hazara to accompany the revised geological map: Wein Jb. Geol. B.A. Sonderban", vol. 15, pp. 5-20, 1970

[8] S.M.I. Shah, "Stratigraphy of Pakistan: Geol. Surv. Pakistan”, Memoirs, vol. 22, pp. 1-381, 1977.

[9] A.H. Kazmi, R.A. Rana, "Tectonic Map of Pakistan, 1:1,000,000”, Geol. Surv. Pakistan, 1982.

[10] A.K. Bhattacharayya, C. Chakraborty, "Analysis of Sedimentary Successions: A Field Manual”, A.A. BalKema, South Africa, pp. 3-16, 2000.

[11] J.L Howard, "The statistics of counting clasts in rudites: a review, with examples from the upper Palaeogene of southern California USA", Sedimentology, vol. 40, no. 2, pp. 157-174, 1993.

[12] K.M. Zahid, D.L. Jr. Barbeau, “Constructing Sandstone Provenance and Classification Ternary Diagrams Using and Electronic Spreadsheet”, J Sediment Res, vol. 81, no. 9, pp. 702-707, 2011.

[13] K. Yagishita, O. Takano, "Recognition of floodplain within broad delta deposits of the Oligocene Mianato Formation, north-eastern Japan: fine deposit correlated with transgression", Spec publs int Ass Sediment, vol. 35, pp. 557-568, 2005.

[14] S. Sarkar, S. Chakraborty, S. Banerjee, P.K. Bose, "Facies sequence and cryptic imprint of sag tectonics in the late Proterozoic Sirbu Shale, Centeral India", Spec publs int Ass Sediment, vol. 33, pp. 369-381, 2002.

[15] T.A. LaMaskin, M. Elrick, "Sequence stratigraphy of the middle to upper Devonian Guilmette Formation, southern Egan and Schell Creek raanges, Nevada", Geol Soc America Spec Paper, vol. 321, pp. 89-112, 1997.

[16] M.E. Tucker, "Sedimentary Petrology", pp. 272, 2001.

[17] S.J. Boggs, "Principles of Sedimentology and Stratigraphy", 4th edn. Pearson Prentice Hall, Upper Saddle River, New Jersey, 2006.

[18] W.C. Krumbein, "Measurement and geological significance of shape and roundness of sedimentary particles", J Sed Pet, vol. 11, no. 2, pp. 64-72, 1941.

[19] T. Roussillon, H. Piégay, I. Sivignon, L. Tougne, F. Lavigne, "Automatic computation of pebble roundness using digital imagery and discrete geometry", Computers \& Geosciences, vol. 35, no. 10, pp. 1992-2000, 2009.

[20] W.R. Dickinson, "Interpreting provenance relations from detrital modes of sandstones", in: G.G. Zuffa, (Ed.), Provenance of Arenites: Boston, D. Reidel Publishing, pp. 333-361, 1985.

[21] G.J. Weltje, “Ternary sandstone composition and provenance: an evaluation of the “Dickinson model”. Geol Soc London, Spec Pub, vol. 264, pp. 7999, 2006.

[22] R.L. Folk, "Petrology of Sedimentary Rock. Hemphill Publishers", Austin, Texas, USA, 1980

[23] R.H. Dott, "Wacke, graywacke and matrix; what approach to immature sandstone classification"? J Sediment Petrol, vol. 34, pp. 625-632, 1964. 